International Journal of Instruction e-ISSN: 1308-1470 • www.e-iji.net
July $2019 \bullet$ Vol.12, No.3

p-ISSN: 1694-609X

pp. $815-832$

Received: 14/12/2018

Revision: 09/05/2019

Accepted: $13 / 05 / 2019$

OnlineFirst:20/06/2019

\title{
Elementary Teacher's Perceptions of Education Reforms in Albania
}

Enkeleda Arapi

Post-doctoral researcher, corresponding author, University of Montreal, Canada, enkeleda.arapi@umontreal.ca

Frederic Lasserre

Prof., Laval University, Canada, frederic.lasserre@ggr.ulaval.ca

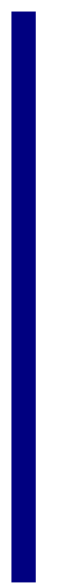

After the fall of the communist regime in 1991, Albania undertook a profound programme of reform to its education system, along similar lines to those reforms being undertaken elsewhere in Central and Eastern Europe. These reforms were political, structural, and pedagogical - altering both the curriculum as well as teaching methods. This article intends to analyse the manner in which these hugely ambitious reforms were received by teachers in Albania, emphasising that it is ultimately those aspects that affect their daily working lives which have caught their attention. The research is based on a qualitative approach discourse analysis of interviews conducted with a sample of 12 teachers in elementary schools in the Tirana region. The results underline the fact that teachers have a fairly accurate understanding of the modernization objectives of the reform; they are positive about the changes to the curriculum and to teaching methods, but their opinions diverge when it comes to the process of choosing textbooks. However, participants appeared to be barely able to remember the political and structural drivers underpinning the reforms.

Keywords: reform, communism, teaching, teachers, pedagogy, perceptions

\section{INTRODUCTION}

In 1944, during the Second World War, the Communist Party took power in Albania, transforming it into the Socialist Republic of Albania. Part of the Eastern Bloc, the state was one of the most isolated in Europe. The social and political movements of the Eastern Bloc in the 1980s, symbolised most memorably by the destruction of the Berlin Wall in 1989, precipitated the fall, in 1991, of Albania's communist regime. The memory of these movements continues to influence Albanian society today. The new regime undertook various political, social, and economic measures in order to transform Albania's Communist system, in place for nearly fifty years, into a liberal economy.

Citation: Arapi, E., \& Lasserre, F. (2019). Elementary Teacher's Perceptions of Education Reforms in Albania. International Journal of Instruction, 12(3), 815-832. https://doi.org/10.29333/iji.2019.12349a 
Since 1991 Albania has attempted to put into place an open society, a market economy, and a form of western democracy. These changes affected the entirety of Albanian society, as everything associated with the ancien regime was, during the years that followed the revolution, systematically reformed or eliminated. This wave of rapid change also affected the education system. For the last two decades, Albania's political leadership has attempted to transform and reorganise the education system into one based to the greatest possible extent on the Western model (Council of Ministers of Albania, 2008; Gardinier, 2012; MASH, 2005), much like their counterparts in the other states of Central and Eastern Europe (Birzea, 1994; Satchkova, 2003).

Albania is currently a candidate for mmethodoloembership of the European Union (EU). Its candidature was submitted in 2009 , and the country has been recognised as an official candidate country since 2012. Although the EU issues common economic, political, and legal directives, it does not do so for education. Nonetheless, although the EU does not develop education standards regulations, it has not been without influence in the matter. The broad principles for recommended education policy in transition states are drawn from the general Pan-European social and economic recommendations relating to labour training and employment (Sahlberg and Boce, 2010; West, 2013). Therefore, Albania, like most of the other transition states in Central and Eastern Europe, has been strongly encouraged to align its education policy with those of the member states of the EU (Cerych, 2002; Hinţea et al, 2004; Lama et al, 2011; Marga, 2002; Satchkova, 2003; Silova, 2004; Zmas, 2012). The same can be said of the ensemble of its administrative reforms (Elbasani, 2004). Furthermore, during the financial turmoil that came in the wake of the communist regime's collapse, Albania sought assistance from the EU and from the World Bank, especially with respect to its education policy. It is through these assistance programs that the EU, the Soros Foundation, the German GTZ and the World Bank, amongst others, contributed to the direction of Albania's education reforms (Bassler, 1995; Cerych, 2002; Gordon \& Pares, 1995; Sultana, 2006).

Traditionally, education policy in Albania was informed by the political ideology of the governing party rather than being founded on principles derived from research in education science, a field practically nonexistent for the fifty years of communist rule (Karapici and Thereska, 1995; Whitehead, 2000; Mullahi \& Dhimitri, 2015). The direction and organisation of the education system was designed to be ideologically compatible with the regime and to efficiently create a well-trained labour force (Dhamko, 2010; Pop-Eleches and Tucker, 2012; Roucek, 1958; Sota, 2014; West, 2013), and thus rested on a highly centralized administrative structure where syllabi, teaching methods and evaluation processes were standardized (Abdurrahmani, 2013; Cerych, 1997; Tuul et al, 2011). However, the communist system was also transformational, in that it had been instrumental to the eradication of illiteracy (Zickel and Iwaskiw, 1994). But in the eyes of the new government, keen to distance itself from the communist regime as much as possible, the existing education system was irreparably tainted by its ideological heritage and was therefore in need of vigorous reform (Birzea, 1994; Birzea, 1996a; Birzea, 1996b; Ibicioglu et al., 2008; West, 2013). 
Nevertheless, Sahlberg and Boce (2010) posit that there are numerous examples where reforms were carried out by a political leadership that lacked even the most basic knowledge about contemporary research on their education system. Therefore, decisions to implement reform were often taken despite a lack of awareness about the strengths and weaknesses of the communist-era system that they had inherited. Rather it became imperative to extirpate any trace of communism from the system, which in practise meant any and all operational and administrative structures put in place before 1991. However, this purge was not necessarily informed by any particular vision of what educational objectives should replace them (Birzea, 1994; Karsten \& Majoor, 1994; Marga, 2002; Nagy, 1994; Sahlberg \& Boce, 2010; West, 2013). This approach to reform, designed entirely around the need to completely erase a rejected legacy without taking proper account of what was working with the old system, was arguably just as driven by ideology as the previous regime was. The desire to remove communism at any cost prevailed over a rational evaluation of the relative strengths and weaknesses of the education policy that it had developed (Cerych, 1995; Marga, 2002; Zmas, 2012). Education occupies a central place in state structures "because of its role in the dissemination of knowledge, encouraging progress and the values of national cohesion" (Van Zanten, 2013, p.2), a fact which justified implementation of the reforms. According to the same author, politics has long influenced the direction of education, but in Western societies governments tend to propose reforms that are based upon science and professional experience, at least in theory. Are these principles being applied by the Albanian government with respect to its education reforms?

In Eastern Europe, it is still unclear how teachers approach curricular expectations prescribed by the state bodies (Maric and Jovanovic, 2017). There is an ongoing debate as to how and whether teachers should take part in reform planning. (Hakala, 1996), although a growing number of authors underline reforms are more likely to be successful with bottom-up processes that involve teachers (Pietarinen et al, 2017; West \& Crighton, 1999). The literature describes successful experiments in Estonia akin to what is enforced in Finland and largely considered as a standard for curriculum reforms involving teachers (Erss, 2018; Tuul et al, 2011;).

The reforms, implemented from 1991 onwards, have been numerous and have profoundly altered the education system. The Albanian government sought to draw resolutely upon an idealised western model in order to radically move away from the methods of the communist regime. Has the ideological pressure of this approach led to hasty reforms that fail to take account of teachers' views? How have teachers perceived and experienced these rapid upheavals between 1991 and 2013? If the literature partly addressed the issue of education reform in Eastern Europe, it did not tackle with the perception of successive major educational reforms by Albanian teachers. This article will attempt to describe the progress of these reforms both in the context of the enormous political upheaval in the years since 1991, and across the different objectives established by successive post-communist governments. It will also recount teachers' perceptions of these reforms (Anonymous, 2016). 


\section{REFORMS OF THE NATIONAL EDUCATION SYSTEM IN ALBANIA}

We were able to trace the evolution of Albania's education reforms through documentary research on the reforms promulgated in the years since 1991, and through the analysis of official government texts. However, there is little published scientific research on the topic, and much of the literature on the broader subject, such as Birzea, 1994, 2012; Radó, 2001; West, 2013 have tended to ignore the reforms. This latter point has been picked up by certain authors, such as Devlin and Godfrey (2004). What are these reforms and what are their aims?

Government policy has for twenty years considered education a national priority, as have most western countries. Beginning in the 1990s, Albania's education system underwent a series of major changes. These can be organised into three key stages, each characterised by important reforms to teaching at the primary and secondary levels.

\section{Key Reform Stages}

The purification of communist characteristics from the education system. The 1990s signified the end of a communist regime that had lasted for fifty years and its replacement by a very fragile democratic system. This political, social, and cultural rupture was also a moment of change for the national education system. The very foundations of the education system inherited from the communist period were called into question, due to the fact that the overriding objective of the old system was to unquestionably promote the values and ideology of the ruling Communist Party. This sudden regime change pushed the new governing elite to completely review the objectives, operation, and values of the education system. This was despite the fact that a considerable section of the new ruling elite was drawn from the dethroned Communist Party. The curriculum, teaching style, values, objectives, as well as the very culture of school life was called into question. However, during this period the principal changes to the system concerned 'the system's 'purification' of the heritage and effects of the communists' ideology" (free translation) (MASH, 2014a). The main tasks of this programme can be summarised as follows: adopt a curriculum free from political manipulation and ideological distortion; implement a relative reduction of the workload; create a better balance between fact-learning, the acquisition of skills, and critical thinking; and re-examine the objectives and content of the social sciences.

The construction of a legal framework for the education system (1995-2010). The second step aimed to prepare a legal framework around which the administration of the new system could be organised. During this second phase the government sought to further its cooperation with various international organisations, including the World Bank. The bank's aid and expertise was especially important to the development of two major projects designed to improve the quality of teaching (in the years 2000-2005 and 2006-2010), as well as to the preparation of a national education strategy (MASH, 2009). These changes affected the structure of the education system, the courses taught, and the management structure. However, despite the energy and money invested into these reform efforts, various evaluations by national and international organisations suggest that student achievement remains weak and that system efficiency, as measured by the academic success rate, is low. The calculation of system efficiency takes into 
account several different criteria, including for example the success rate for exams held at the end of secondary school, as well as the student drop-out rate (MASH, 2014b).

Modernise the education system. This stage of the reform program aimed to democratise the education system by integrating the principles of equality of opportunity and the respect of diversity; quality education should be available to all. No longer was the objective to purge traces of the communist past, nor to transform the administrative structure, but rather to expand the content of the taught programme and to modernise teaching methods. A key objective then was to reform the way education was governed through a process of decentralisation, as Albania's system remains highly centralised compared to the western standard (MASH, 2009). Another objective was to improve the overall quality of the teaching process, for which the following priorities were identified: modernise the curriculum; improve the professional development of teachers; increase the quality of school textbooks; and improve student evaluation methods.

The modernisation of the curriculum appears to have proved particularly important to the improvement of the quality of teaching. As an illustration of this, Janaqi (2014) reveals how the current curriculum is based around the individual pupil with a flexible programme adapted to their needs and interests. This approach is radically different to the traditional system whereby the pupil was obliged to adapt to a one-size-fits-all model of rote learning based around the teacher. The current curriculum instead proposes a system whereby pupils and teachers work together, where education is adapted to the learning style of each student, and one where students are encouraged to acquire skills and to critically develop solutions to the personal and social challenges that they will face in life. The modernisation of the curriculum also seeks to promote an education system with a more international outlook. Notably this includes the addition to the curriculum of two foreign languages, information and communication technology (considered particularly important to prepare students for the challenges of today's interconnected world), and a greater emphasis on lifelong learning.

But more importantly than these noble principles, the primary objective of the reform programme is to create the best possible conditions for student learning, irrespective of student ability and social origin (the principle of equality of opportunity). This is considered crucial to the creation of an active citizenry able to creatively and critically participate in the country's economic, social, and cultural life, and to the development of a true democratic society. If the underlying principle (equality of opportunity) remains the same as that of the communist system, the objectives differ in that their aim is to create active citizens who are prepared for employment in the free market system.

In fact, Albania's most recent reforms broadly share the same objectives as those undertaken in the West; i.e. "adapting the education system to the specific needs of a given society; improvements to the learning environment; improving training methods and graduate-level development to meet the demands of the jobs market." This means reforms founded on the principle of learning skills, improvements to teacher-training, and a pupil-centric approach to teaching (Lafortune, Ettayebi \& Jonnaert, 2006).

\section{The Objectives of the Most Recent Reforms}

Skills development and a pupil-centric approach 
The key skills of Albania's school curriculum are still in development, but they are broadly inspired by those of the West: France, Switzerland, Great Britain, Finland, Québec, etc. (Janaqi, 2014). They are divided into the following seven areas: 1. Communication skills; 2. Reasoning skills; 3. Learning techniques (learning how to learn); 4. Life, business, and environmental skills; 5. Personal and social skills; 6. Civic skills; 7. Computer skills. These are skill sets that are commonly taught within school programmes across the West.

The same author highlights that the traditional pre-reform curriculum put a far greater emphasis on the teacher rather than the pupil, and placed the acquisition of academic knowledge above the development of skills. The curriculum's structure was rigid, inflexible and highly centralised. It stressed rote learning and the regurgitation of precise, 'prefabricated', facts. By contrast, the new pupil-centric curriculum places a greater value on the learning processes themselves, and is built upon the idea of a multidisciplinary methodology (the principle of skills-learning). Furthermore, it is much more flexible in terms of structure and time allocation. The system is open to the community at large and encourages lifelong learning. The positive effects of the new curriculum are illustrated by Albania's Pisa scores, which according to the OECD (2012) improved considerably between 2000 and 2012. By way of example, Albania has managed to both increase the number of high performing students in mathematics, and reduce the number of students who were underperforming in writing skills.

The reforms have attempted to concentrate on the curriculum and the place of the student, but neither has it neglected teacher training, primary teaching, and ongoing professional development. Research underlines however it is not easy to evaluate the impacts of these reforms (Abdurrahmani, 2013; Abdurrahmani \& Boce, 2011; Gjedia \& Gardinier, 2018).

The importance of teacher training.

According to MASH (2014a) the teaching profession is closely overseen and the required standards are high. In order to gain qualified teacher status in Albania, each candidate must complete a graduate-level teaching degree geared to their subject of specialisation; undertake and complete a one-year professional internship in a 'complementary education' institution; and pass the final state exam for their chosen teaching profile.

Because of this, Ikonomi et al. (2009), based on studies undertaken by Pantić (2008); Rajković \& Radunović (2007) as well as Zgaga (2006), state that in the Balkan region teachers are adequately prepared; existing training programmes are built upon an appropriate foundation of theoretical and disciplinary knowledge and skills. Nevertheless, there remain certain gaps and weaknesses. Initial teacher training, as well as career development training and evaluation (Leka, 2016), tends to overlook the importance of practical experience and fails to expose candidates to the daily realities of teachers. For example, there is insufficient attention paid to preparing teachers for the various external factors inherent in school life, such as the participation of parents and the wider community in schooling. Such things are hardly considered. In response to this, Ikonomi et al. (2009) recommend that training programmes take greater account of 
the skills necessary for teachers to adapt to a social environment that has undergone major changes. This recommendation builds upon those of Whitehead, who in 2000 looked at the structure of internship programmes as part of the wider education reform programme. In the wake of these reforms, his study found that universities restructured their teacher training programmes to increase the amount of time assigned to undertaking professional internships. However, he also found that the implementation of these changes was slow, and was further disrupted by the events of 1997 (Albania's political crisis) and the War in Kosovo in 1999. Furthermore, these events made it difficult to asses the progress of Albania's reforms during this period, and complicated communication between academics in Albania and their partners based out of European universities elsewhere.

Overall, the objectives and nature of Albania's education reforms in recent years broadly resemble the typology proposed by Cerych (1997)) of reforms undertaken elsewhere in Central and Eastern Europe. We can summarise this typology thus:

- Corrective reforms aimed to correct the most apparent characteristics of communist education;

- Modernisation reforms aimed at updating the curricula, textbooks, equipment and teaching methods;

- Structural reforms which relate, for example, to changes in the length of studies, and changes between different levels and kinds of education;

- $\quad$ Systemic reforms, involving a paradigmatic shift in, for example, decentralisation and the redefinition of the role of the state to enable the emergence of a pluralistic democracy, the pursuit of market economy principles in educational organisations and the implementation of quality control through evaluation and public accountability.

"Regarding the process of restructuring, the situation in Albania is similar to that in the majority of Central and Eastern European countries and has been primarily a bottom-up process. The Ministry has been involved in, but has not directed, teacher training reforms, thereby marking a break with the former system of centralised control". (Whitehead, 2000). If in theory these reforms aim to reorganise education according to Western norms, how did the actors affected by these changes, principally teachers, respond to them?

\section{METHOD}

In order to examine teachers' perceptions of the reform programme, this study used a qualitative sampling approach. In this kind of approach, it is the experiences and events which teachers themselves cite that are important. As Miles and Huberman (2009) put it, qualitative sampling aims to produce a theoretical representativeness and not a statistical representativeness. Moreover, this approach seeks to describe and analyse the significance of participants' experiences. The choice of site and sample was made according to the objectives of the research.

The research site consists of three primary schools in the country's capital city, Tirana. Two of these schools were located in better-off neighbourhoods, and one in a less well- 
off area. The participants were recruited on a voluntary basis through a call to participate disseminated by the administration of the three schools. The sample is composed $n=12$ primary school teachers, of which $n=6$ teach in the fourth year, $n=3$ in the second year, and $n=3$ in the third year. Most participants $n=11(91.6 \%)$ were women. Furthermore, slightly more than half $n=7(58 \%)$ of participants were aged between 36 and $40 ; n=3$ participants were aged 31 to 35 , and $n=2$ participants were more than 41 years of age. The sample consisted of 5 participants who had between 7 and 10 years of experience; 3 participants who had between 10 and 15 years of experience, and only 2 participants who had taught for more than fifteen years. The majority of teachers $n=10$ $(83 \%)$ possessed a bachelor's degree in primary education; only $n=2$ possessed a master's degree (Table 1).

Table 1

Characteristics of the Studied Sample

\begin{tabular}{cc}
\hline Characteristics & $n$ \\
\hline Teacher's Gender & 11 \\
Woman & 1 \\
Man & \\
Academic year & 3 \\
$2^{\text {nd }}$ grade & 3 \\
$3^{\text {rd }}$ grade & 6 \\
$4^{\text {th }}$ grade & \\
Teacher's age & 3 \\
$31-35$ & 7 \\
$36-40$ & 2 \\
$41+$ & \\
Teacher's years of experience & 2 \\
Less than 5 & 5 \\
$5-10$ & 3 \\
$10-15$ & 2 \\
$15-20$ & \\
Education level & 10 \\
Bachelor & 2 \\
$2^{\text {nd }}$ cycle degree & \\
\hline
\end{tabular}

Data collection consisted of semi-guided interviews. In a semi-guided interview, the researcher initiates and guides the discussion through a series of prepared questions, but leaves the conversation open for the respondent, adapting or modifying if necessary the order and wording of the questions asked (Paillé and Muchielli, 2016). Interviews took the form of individual meetings between the researcher and the participant. They took place in 2013 in the three chosen schools of Tirana, Albania's capital. Interviews with each teacher lasted 45 minutes, and aimed to draw out their opinions on the reforms.

Participants were asked to respond to questions about their perceptions of the education reforms. The semi-guided interview consisted of two parts. The first was composed of questions about the teacher's understanding of the reform programme and their attitudes towards it. The second sought to uncover teacher's perceptions of the changes that arose from the implementation of these reforms. Questions guided the participant towards expressing their opinion with respect to three principal areas: changes in the teaching and learning process; teacher-pupil relations; and teacher-parent relations. 
A thematic analysis approach is used. The analysis of content allows us to "identify the meaning, or meanings, of what is presented, and to formulate and classify everything contained within the discourse" (Paillé and Mucchielli, 2016). According to Mace and Pétry (2010), thematic analysis serves principally to analyse the discourse of actors in order to study their "intentions or motivations." The steps of the content analysis are sketched out in Table 2.

Table 2

The Steps of Content Analysis for the Present Research

\begin{tabular}{|c|c|c|}
\hline Step & Characteristics of qualitative analysis & Characteristics of content analysis for this study \\
\hline Pre-analysis & $\begin{array}{l}\text { Prepare the data set that will be } \\
\text { integrally transcribed }\end{array}$ & $\begin{array}{l}\text { The teacher interviews were transcribed into a Word document. The } \\
\text { complete transcription of the data was done concurrently with the } \\
\text { data collection (Huberman \& Miles, 2003; Strauss \& Corbin, 1998). }\end{array}$ \\
\hline Codification & $\begin{array}{l}\text { Transform raw data into concise and } \\
\text { easily detected terms. }\end{array}$ & $\begin{array}{l}\text { A careful reading of all the verbatims was made. Then we } \\
\text { established a coding system to classify the empirical data. The } \\
\text { coding was conducted at the word, line or paragraph level as the } \\
\text { unit of meaning. (Krippendorf, 2004; Huberman \& Miles, 2003). } \\
\text { The codification was carried out with the TAMS software. }\end{array}$ \\
\hline Categorisation & $\begin{array}{l}\text { Define categories enabling the } \\
\text { grouping of identical answers (codes) } \\
\text { under a generic heading. }\end{array}$ & $\begin{array}{l}\text { As a result of the preliminary analysis of the data collected and } \\
\text { based on the research questions, the codes were grouped into } \\
\text { categories. An analytical grid was created according to } \\
\text { predetermined themes inspired by the review of the literature and the } \\
\text { theoretical framework. Some categories of codes also emerged from } \\
\text { the data collected. }\end{array}$ \\
\hline $\begin{array}{l}\text { Links } \\
\text { definition }\end{array}$ & Define links between categories. & $\begin{array}{l}\text { Links between categories were established according to weight, sub- } \\
\text { themes, complementarity and opposition. }\end{array}$ \\
\hline $\begin{array}{l}\text { Data } \\
\text { Articulation }\end{array}$ & $\begin{array}{l}\text { Highlight the relationships established } \\
\text { between the themes in order to ensure } \\
\text { a deeper and more interpretive } \\
\text { understanding. }\end{array}$ & $\begin{array}{l}\text { Quantification and statistical processing were conducted. The } \\
\text { presentation of the data was done with tables and figures that are "a } \\
\text { compact form immediately accessible" according to Huberman \& } \\
\text { Miles (2003). }\end{array}$ \\
\hline $\begin{array}{l}\text { Conclusions } \\
\text { formalization }\end{array}$ & $\begin{array}{l}\text { Give meaning to codified data, } \\
\text { formulate explanations and organize } \\
\text { possible relationships. }\end{array}$ & $\begin{array}{l}\text { After organizing and presenting the results, we tried to make sense } \\
\text { of what the data tells about the teachers perceptions of reforms. }\end{array}$ \\
\hline
\end{tabular}

The analysis of participant discourse is focused on two principal themes: 1) the nature of the education reforms, and 2) the changes which arise from the implementation of these reforms. Table 3 illustrates the themes and categories according to which the analysis of participant discourse was undertaken.

Table 3

Analysis Themes and Categories

\begin{tabular}{lll}
\hline Theme & Category & Description \\
\hline $\begin{array}{l}\text { The type of } \\
\text { education reform }\end{array}$ & $\begin{array}{l}\text { Corrective reforms aimed to correct } \\
\text { the most apparent characteristics of } \\
\text { communist education } \\
\text { Systemic vision: decentralisation of } \\
\text { the state's role }\end{array}$ & $\begin{array}{l}\text { Questions on descriptions, examples, } \\
\text { perceptions, means, explanations,r } \\
\text { representations. Type of open questions: } \\
\text { how, which, when, why, }\end{array}$ \\
\hline $\begin{array}{l}\text { Changes arising } \\
\text { from reform } \\
\text { implementation }\end{array}$ & $\begin{array}{l}\text { Curricula, textbooks, lifelong learning } \\
\text { Teaching methods } \\
\text { The place of the pupil } \\
\text { School-family relations }\end{array}$ & $\begin{array}{l}\text { Questions about descriptions, examples, } \\
\text { perceptions, means, explanations, } \\
\text { representations. Type of open questions: } \\
\text { how, which, when, why, }\end{array}$ \\
\hline
\end{tabular}

Whilst of course this small urban sample does not offer a comprehensive portrait of the opinions of the country's entire teaching staff, it does permit us to identify perceptions in a region that nonetheless contains more than a third of Albania's population. 


\section{FINDINGS}

This section develops concurrently the results of our analysis and opens to a discussion of the perception by teachers on educational reforms, their implementation and the changes these reforms introduced in the daily work conditions of teachers.

\section{The Nature of Education Reforms}

The reforms were accompanied by tools and mechanisms which organised and governed the implementation of changes. However, it seems that these tools and mechanisms have not always been actually accessible to teachers in their daily work. By analysing teacher's responses, we came to realise that our questions relating to the content of the reform programme were not the easiest for teachers to answer. Teachers did not seem particularly familiar with reform objectives such as correcting the most apparent characteristics of communist education; the decentralisation and the redefinition of the role of the state to enable the emergence of a pluralistic democracy; the pursuit of market economy principles in educational organisations; and the implementation of quality control through evaluation and public accountability.

As far as the first objective goes, it is perhaps understandable that this did not seem to be a priority for teachers. After all, more than two decades on from the change of regime the principal political upheavals are something of the past and therefore no longer stimulate debate. The second objective, the decentralisation of the state's role, appears simply not to factor into teachers' concerns; none of them made any reference to this subject during the interviews.

\section{What Do the Reforms 'Modernise'?}

The question of modernisation appeared to be the most accessible and that which preoccupied teachers the most. Participants' discourse on the subject allows us to identify various opinions on this general reform objective via its practical manifestations, such as changes to the curriculum, to textbooks, to equipment, and to teaching methods. The majority of teachers focused on teaching methods, the attitude and role of pupils, changes to the choice of textbooks, and the nature of project-based learning. For example, one teacher's answer focused on the learning process, the place and role of pupils, and the role of conceptual learning:

"The reforms have changed a lot of things, including the teaching process, its content and its form. I've seen how the teaching style is very, very different. We concentrate more on concepts and their applications in different fields, and not just in the subject that I teach. The pupil is at the centre of the teaching process, and they participate more...they communicate much more with me." (Resp. 3)

Teacher's responses often complemented each other. Thus, another teacher concentrated on the application of personalised pedagogy in respect of pupil's different needs. The teacher insisted upon the importance of this kind of pedagogy as part of the reforms:

"The work of teachers has changed, and the pedagogical methods are different, for example by personalising pedagogy according to pupil ability, and I think it's good for the pupils...the curriculum has changed too, and there are more concrete examples in the textbooks." (Resp. 5). 
In the same vein, teachers spoke about a major component of the reforms: the decentralisation of the education system via textbook choice and flexibility in their content. 8 out of 12 participants gave an opinion on course content and the choice of compulsory school manuals that derived from this. However, their opinions were ambivalent. A quarter of teachers were positive about the current textbooks. There are several options, texts are customised, and they are more interesting for the reader:

"The manuals (textbooks) that we use today are better, more attractive, more interesting, and more comprehensive (images, questions, exercises, concrete examples) ... and they are simpler." (Respondent 7)

By way of contrast, participants criticised the selection procedure for textbooks. These criticisms focused on different aspects, and out of our sample, four gave an opinion on the flexibility of textbook choice:

"At the beginning of the reforms, we had greater flexibility in the choice of texts. Now we don't really have a choice. I must choose between those texts that have already been chosen by the management. I would have liked to choose texts according to class ability so as to adapt my teaching." (Resp. 9).

Or, for example:

"The choices are made in the committees...they should be made in the schools, according to the level of the schools and the ability of the pupils." (Respondent $5)$.

Another participants' reflections on the subject further reinforces the idea that the teacher's role is crucial in the textbooks selection process. Additionally, the participant raises the problem of using different school textbooks for the same subject:

"With the reform, there are several manuals: there should be just one instead of suggesting several. Now each school decides which publisher to use. The decision makers should ask for the teachers' opinions a bit more. It would be fairer and more coherent to use the same manual instead of each school deciding which book to use..." (Respondent 4).

The following participant focuses instead on textbook content. Interestingly, the majority (10 out of 12 teachers) expressed concerns about the selection process for textbooks, whereas only two mentioned their actual content.

"The current texts put more emphasis on oral ability. Personally, I think we should also find textbooks that emphasise written ability. Writing should also be a priority." (Respondent 11)

Our interviews clearly illustrate that as far as professional practices and personal attitudes are concerned; the reforms have definitively left their mark. Moreover, they divide opinion. 4 out of 12 teachers observed that they were initially anxious about the reforms, but with time ended up adapting.

"There have been a lot of reforms. Initially, I was reticent about them. They weren't very clear and I had trouble finding my feet. I took a few training courses which helped me to better understand the changes such as class 
preparation and the new evaluation methods... but it took time at first." (Respondent 1)

This teacher's attitude is understandable given the size and number of changes introduced by the reforms. Additionally, the teachers are well aware that there are further reforms to come.

"Yes, I think that there are still changes to be made, especially with regards to project-based learning. I think that we still need to further adapt the way we work according to student ability, but you know parents can't always help their kids, the parents are a bit hesitant." (Respondent 3)

Other topics raised by the participants include class management, pupil attitudes, and parent participation. Teachers felt that the reforms had also had an indirect impact on these aspects. The following excerpt discusses the new method of placing the pupil at the centre of the learning process, an innovation which has somewhat altered the way teachers view them.

"I think the pupils have changed in the last few years. With the new method pupils participate more, they ask more questions, they communicate more easily, and they are more familiar with their rights as well... Actually, it is easier to teach today than with the traditional method because pupils are more active." (Respondent 8)

However this was not the prevailing view, as only 5 out of the 12 thought that class management was easier because "pupils are more active in their learning, they ask questions more...they're more interested" (Respondent 10). The other teachers were more critical with respect to pupil attitudes:

“Pupils are different today. Their behaviour isn't always appropriate, there's a lack of interest..." (Respondent 4)

This opinion is shared by another teacher:

“There's been a lot of change in pupil behaviour, they're not always friendly or polite (influence of TV, friends, society); they're more demanding, they insist upon having more rights. I have the impression that they're less respectful than before."

Class management has a lot to do with the quality of the pupil-teacher relationship. Teachers raised several points in response to questions about the reforms' impact on this relationship. Pupils are described as being more stimulated and engaged with the taught material. They also noted improvements in pupils' communication ability.

This brings us to the final issue raised by the teachers: relations with parents. This was a sensitive topic. Participants appeared critical of parents' attitudes:

"Relations with the parents are a bit more complicated, as most parents think this is the school's responsibility and therefore are more demanding of us. Teachers are no longer respected, and I don't have the impression that our work is as valued as before, when teachers were both respected and valued." (Resp. 10) 
This opinion is shared by more than half of participants. Teachers felt that better-off parents were particularly likely to put pressure on the school and to have high expectations:

"Parents expect more, and from the school and its teachers rather than of their children... Schools are responsible for student success and for education, but parents too, right...?"

Teachers also underlined that after the reforms, parents have proved less engaged with their children at school.

“There's less parent engagement, they're not always present at parent-teacher meetings, they participate less. Parents are a bit destabilised, a bit disorientated by the reform, by certain aspects. I've tried to explain them during our meetings. But it isn't sufficient." (Respondent 10).

This said, are teachers' changed opinions of parents really a result of the reform, or of the broader changes that have affected Albanian society? The reforms have assigned an even greater place for parents within the system than before, by specifying the role and responsibilities of parents vis-à-vis their children's education. By way of example, the reforms have created school boards, an innovation for Albania.

\section{DISCUSSION}

Overall, the analysis of teachers discourse illustrate how short, or at least very concise, the teacher's responses were with respect to the pedagogic aspects of the reform programme, e.g, learning styles, the curriculum, and teaching methods. We conclude from this that whilst the teachers appear to broadly understand the reform programme's objectives, they rarely seem to dwell on them in much detail. Perhaps the finer points of the reforms have not been adequately explained to the teaching staff? Perhaps there are communication problems between the government, the education department, and frontline staff? There are various possible explanations, but our objective is to examine how schoolteachers experienced and perceived the changes that have followed the reforms.

The very objective of reforms was to completely transform teaching methods at the same time as improving education programmes through a reorganisation of the curricula. Nonetheless, 9 out of 12 respondents agreed that the changes wrought by the reform were positive for teaching methods, for the education program, and for learning. In contrast, the teachers see the positive aspects of the reforms as a product of the training sessions that accompanied their implementation, rather from the reforms themselves. 8 out of 12 respondents underlined the importance of these training sessions in helping them understand the reform's changes.

Class management appears to be a sensitive subject for the teachers. 5 out of 12 respondents found that class management is more difficult now than it was. The transition "from the traditional system whereby the teacher explains everything and the pupil sits listening passively" to a rather more "active" method (Resp. 1) has forced teachers out of their comfort zone and demanded that they make some occasionally difficult adjustments. 
Dialogue between pupils and teachers has become easier to establish, and is more constructive. A majority of participants, 8 out of 12, thought that the reforms have had positive effects on learning by stimulating student motivation and teacher-pupil interaction. This group however also suggested that pupils nowadays suffer from cognitive overload. Overall, whilst 9 out of 12 participants thought that reforming education to make it more pupil-centric was an important part of the reform programme, these same 9 were also aware that this had been accompanied by a change in pupil behaviour, problems for class management, and problems associated with external actors such as parents. As far as relations with parents are concerned, teachers feel the reforms gave way to more complicated relationships with parents in a frame of decreasing prestige associated with the profession.

The picture drawn from the discourse analysis underlines teachers are aware of the content of reforms and generally welcome the principle of reforms. They are however unsure of the details of these reforms on their daily set of tasks and wish there were more information communicated or more involvement of teachers in the reform process. They are also worried about the orientation toward a more pupil-centered education, with the relationship with parents and their professional status.

This is in line with the analysis of reforms in other countries of Eastern Europe. Educational reforms in Eastern Europe face two sets of difficulties. First, the State does not easily give up its control on education: teachers in the Western Balkans see their involvement in decision- and policy-making as very low (Maric \& Jovanovic, 2017). True, the depoliticization objective led to the breaking down of the State monopoly and the decentralization of the administration of school system (Cerych, 1999). This dismantling of the local mechanisms of state control did not mean teachers felt they were active participants, as Olek underlined for Polish teachers in 1998 (Olek, 1998). Rather, this process usually led to a greater dependence on the national ministries of education (Cerych 1999). Second, many teachers still do not feel comfortable about accepting the responsibility of involvement in curriculum reform (Tuul et al 2011), as already pointed out by Polyzoi and Cerna (2001) in the Czech Republic. Cerych (1999) had already underlined this inertia of teachers inherited from the communist period; this overreliance on the State, and the lack of teachers' experience and competence necessary to get involved at national and local levels of reform processes. In Albania as in other states in Eastern Europe, despite the desire to inject more autonomy in the education system along the line of Western discourse, the reforms did not automatically develop greater teacher participation in the educational reform process (Tuul et al 2011). However, the research underline that reforms, in order to be properly enforced, must take into account the opinion of the actors that will enact it.

\section{CONCLUSION}

From what we can surmise based upon reports, government documents, and empirical research, the reforms appear to be moving Albania's education system further towards the Western model. If official documents closely measure the progress of these Westerninspired reforms, teachers instead focus on the impacts to their teaching. 
Teachers therefore have a fairly accurate understanding of those aspects of the reform programme which are concerned with modernising the curriculum, textbooks, and teaching methods. If they are positive about the changes to the curriculum and to teaching methods, their opinions diverge when it comes to the process of choosing textbooks, an aspect that we would like to address through consultation with the affected actors. Furthermore, teacher's principal concerns were often driven by their daily preoccupations: class management, the place of the pupil, parent-teacher relations, approaches to teaching, etc. It should be underlined however that this research is merely exploratory and draws upon a limited sample.

Nonetheless, teacher's statements have been revelatory. Participants appeared to be barely able to remember the grand political and structural drivers underpinning the reforms. At the very least they do not talk about them. Rather than taking into account the entirety of the reform's objectives and implementation strategies, teachers have instead developed views that concentrate on the impact to their daily working lives. In this sense, the value of our research is found not only in the illustration of teacher's opinions with respect to education reform in a country with a long history of communism, but also in contributing to a broader reflection upon the modernisation of education systems. These results underline the need, for a better implementation of reforms, of teachers' involvement through discussion between them and the political and administrative deciders.

This research was carried out in the Tirana region; similar investigations could be carried in other regions so as to bring a more accurate national picture and have a larger sample. Further research could also involve interviews with school directors that act as the interface between teachers and the administration: they could usefully complement the picture of how the reforms were introduced with schools and teachers.

\section{REFERENCES}

Abdurrahmani, T. (2013). The teacher qualification scheme: a case of Albania. Problems of Education in the 21st Century, 55,11-27.

Abdurrahmani, T., \& Boce, E. (2011). Pre-service, teacher training reform in Albania: a review. In P. Picard \& L. Ria (Eds.), Beginning teachers: a challenge for educational systems - CIDREE Yearbook 2011 (pp. 209-222). Lyon: ENS de Lyon, Institut français de l'Éducation.

Bassler, T. (1995). Beginning a transformation of learning in Albania. European Journal of Education, 30(3), 307-315.

Birzea, C. (1994). Les politiques éducatives dans les pays en transition. Strasbourg: Presses du Conseil de l'Europe.

Birzea, C. (1996a). Educational reform and power struggles in Romania. European Journal of Education, 31(1), 97-107.

Birzea, C. (1996b). Education in a World in transition: Between post-communism and post-modernism. Prospects, 26(4), 673-681. 
Birzea, C. (2012). Learning from post-communist transitions: the case of educational reforms in Central-Eastern Europe. Working Paper published by the Legatum Institute, Educational Reform, 12 November 2012, London.

Cerych, L. (1995). Educational reforms in Central and Eastern Europe. European Journal of Education, 30(4), 423-435.

Cerych, L. (1997). Educational Reforms in Central and Eastern Europe: processes and outcomes. European Journal of Education, 32(1), 75-96.

Cerych, L. (2002). Higher education reform in the Czech Republic: A personal testimony regarding the impact of foreign advisers. Higher Education in Europe, 27(12), 111-121.

Devlin, P. J., \& Godfrey, A. D. (2004). Still awaiting orders: Reflections on the cultural influence when educating in Albania. Accounting Education, 13(3), 347-364.

Dhamko, S. (2010). Boboshtica një variant historie. Korçë: Non-published manuscript.

Elbasani, A. (2004). Albania in transition: manipulation or appropriation of international norms? Southeast European Politics, 5(1), 24-44.

Erss, M. (2018). 'Complete freedom to choose within limits' - teachers' views of curricular autonomy, agency and control in Estonia, Finland and Germany. The Curriculum Journal, 29(2), 238-256.

Gardinier, M. P. (2012). Agents of change and continuity: the pivotal role of teachers in Albanian educational reform and democratization. Comparative Education Review, 56(4), 659-683.

Gjedia, R., \& Gardinier, M. P. (2018). Mentoring and teachers' professional development in Albania. European Journal of Education, 53(1), 102-117.

Gordon, J., \& Parkes, D. (1995). Changing issues in vocational education and training: an Albanian example. European Journal of Education, 30(4), 467-477.

Hakala, J. (1996). Curricular reform, constantly changing values and consequences for teacher education. Scandinavian journal of educational research, 40(2), 175-184.

Hinţea, C., Şandor, S. D., \& Junjan, V. (2004). Administrative reform in Romania and the European Union. In Dimitrova, L. (Eds.), Driven to change: The European Union's enlargement viewed from the East (p.145-162). Manchester: Manchester U. Press.

Ibicioglu, H., Baysal, H., \& Ozkul, A.S. (2008). The role of high education in entrepreneurship training in respect of transition economies-Albania sample. Proceedings of the First International Conference on Management and Economics, ICME, University of Epoka, 2005. Tirana.

Janaqi, G. (2014). Teaching and the curricular framework in the Republic of Albania. Pedagogical Review (Revista pedagogike), 2014, 29-105.

Karapici, G., \& Thereska, N. (1993). Republic of Albania institutional objectives: the need for internal reforms. In Pilot Project on Regional Co-Operation in Reforming Higher Education (Sponsored by EC/Phare). Seminar IV: Professional and Social Competence. OECD/GD(95)50 (74-80). Paris: OECD. 
Karsten, S., \& Majoor, D. (1994). Epilogue: Differences and similarities in Hungary, Czechoslovakia and Poland. In S. Karsten, D. Majoor (Eds.), Education in East Central Europe: Educational changes after the fall of communism (pp.157-164). Münster: Waxman.

Lafortune, L., Ettayebi, M. \& Jonnaert, P. (eds.). (2006). Observer les réformes en éducation. Quebec City : Presses de l'Université du Québec.

Lama, I., Sula, A., \& Gjokutaj, M. (2011). Current issues of teacher training in Albania. Problems of Education in the 21st Century, 32, 47-57.

Leka, K. (2016). Teacher evaluation policies in Albania. Academic Journal of Interdisciplinary Studies, 5(2), 145-150.

Marga, A. (2002). Reform of education in Romania in the 1990s: A retrospective. Higher Education in Europe, 27(1-2), 123-135.

Maric, D. \& Jovanovic, R. (2017). Teachers on teaching: How practitioners see the current state and future developments in history education across the Western Balkans. Research Report. The Hague: Euroclio.

MASH [Ministry of Education and Science of Albania] (2005). National education strategy, 2004-2015. Tirana: Republic of Albania Ministry of Education and Science. Retrieved from: http://planipolis.iiep.unesco.org/upload/Albania/Albania-EducationStrategy-2004 2015.pdf.

MASH [Ministry of Education and Science of Albania] (2009). Strategjia Kombëtare e Arsimit Parauniversitar 2009 - 2013 [National Strategy for Pre-University Education 2009 - 2013]. Tirana.

MASH [Ministry of Education and Science] (2014). Grupi I Punës Për Reformimin E Arsimit Parauniversitar - Reforma E Sistemit Arsimor Parauniversitar. Raporti Paraprak. [Working Group on Pre-University Education Reform - Reform of the PreUniversity Education System. Preliminary Report]. Tirana.

MASH [Ministry of Education and Science] (2014b). Undergraduate curricular framework in Albania. Tirana.

Mullahi, A., \& Dhimitri, J. (2015). Education issues in a totalitarian state (case of Albania). Procedia-Social and Behavioral Sciences, 174, 4103-4107.

Nagy, M. (1994). Hungary. In S. Karsten, D. Majoor (Eds.), Education in East Central Europe: Educational changes after the fall of communism(p.29-75). Münster: Waxman.

Miles, M. B., \& Huberman, A. M. (2009). Analyse des données qualitatives. Bruxelles: De Boeck Supérieur.

Olek, H. (1998). Educational research in Central and Eastern Europe: A diverging tradition? Educational Research and Evaluation, 4(1), 78-93.

Paillé, P., \& Mucchielli, A. (2016). L'analyse qualitative en sciences humaines et sociales, $4^{\text {th }}$ ed. Paris: Armand Colin.

Pietarinen, J., Pyhältö, K., \& Soini, T. (2017). Large-scale curriculum reform in Finland-exploring the interrelation between implementation strategy, the function of the reform, and curriculum coherence. The Curriculum Journal, 28(1), 22-40. 
Polyzoi, E., \& Černá, M. (2001). A dynamic model of forces affecting the implementation of educational change in the Czech Republic. Comparative Education Review, 45(1), 64-84.

Pop-Eleches, G., \& Tucker, J. A. (2012). Post-communist legacies and political behavior and attitudes. Demokratizatsiya. The Journal of Post-Soviet Democratization, 20(2), 157-166.

Radó, P. (2001). Transition in education policy making and the key educational policy areas in the Central-European and Baltic Countries. Budapest: Open Society Institute/Institute for Educational Policy.

Republic of Albania Council of Ministers. (2008). National strategy for development and integration, 2007-2013. Tirana/Council of Ministers. Retrieved from: unstats.un.org/unsd/dnss/docViewer.aspx?docID=2198

Roucek, J. S. (1958). The Sovietization of Albanian education. The Slavic and East European Journal, 2(1), 55-60.

Sahlberg, P., \& Boce, E. (2010). Are teachers teaching for a knowledge society? Teachers and Teaching: Theory and Practice, 16(1), 31-48.

Satchkova, E. (2003). L'éducation bulgare, du communisme à la démocratie : l'expérience d'une transition achevée. Carrefours de l'éducation, (1), 136-158.

Silova, I. (2004). Adopting the language of the new allies. In G. Steiner-Khamsi (Eds.), The global politics of educational borrowing and lending (p. 75-87). New York: Teachers College Press.

Sota, J. (2014). Educational phenomena in Albania in the years of communist dictatorship and the reformation efforts after nineties. ESJ, 11, 31-46.

Sultana, R. G. (2006). Facing the hidden drop-out challenge in Albania. Evaluation report of hidden drop-out project. UNICEF Country Office: Tirana.

Tuul, M., Ugaste, A., \& Mikser, R. (2011). Teachers' perceptions of the curricula of the Soviet and post-Soviet eras: A case study of Estonian pre-school teachers. Journal of Curriculum Studies, 43(6), 759-781.

West, J. (2013). Vocational education and training in Eastern Europe: Transition and influence. LLAKES Research Paper 41, Centre for Learning and Life Chances in Knowledge Economies and Societies

West, R. \& Crighton, J. (1999). Examination reform in central and eastern Europe: Issues and trends. Assessment in Edu.: Principles, Policy \& Practice, 6(2), 271-289.

Whitehead, J. (2000). Teacher education reforms in Albania. European Journal of Teacher Education (1), 85-94.

Zickel, R., \& Iwaskiw, W. R. (1994). Albania: A country study. DC: Library.of Con.

Zgaga, P. (2010). La formation des enseignants dans les Balkans Occidentaux. Revue internationale d'éducation de Sèvres, (55), 129-140.

Zmas, A. (2012). The transformation of the European educational discourse in the Balkans. European Journal of Education, 47(3), 364-377. 